\title{
LOESS TOWARDS (GEO) TOURISM - PROPOSED APPLICÁTION ON LOESS IN VOJVODINA REGION (NORTH SERBIA)
}

Djordjije A. Vasiljević, Slobodan B. Marković, Thomas A. Hose, Ian Smalley, Ken 0'Hara-Dhand, Biljana Basarin, Tin Lukić, Miroslav D. Vujičić

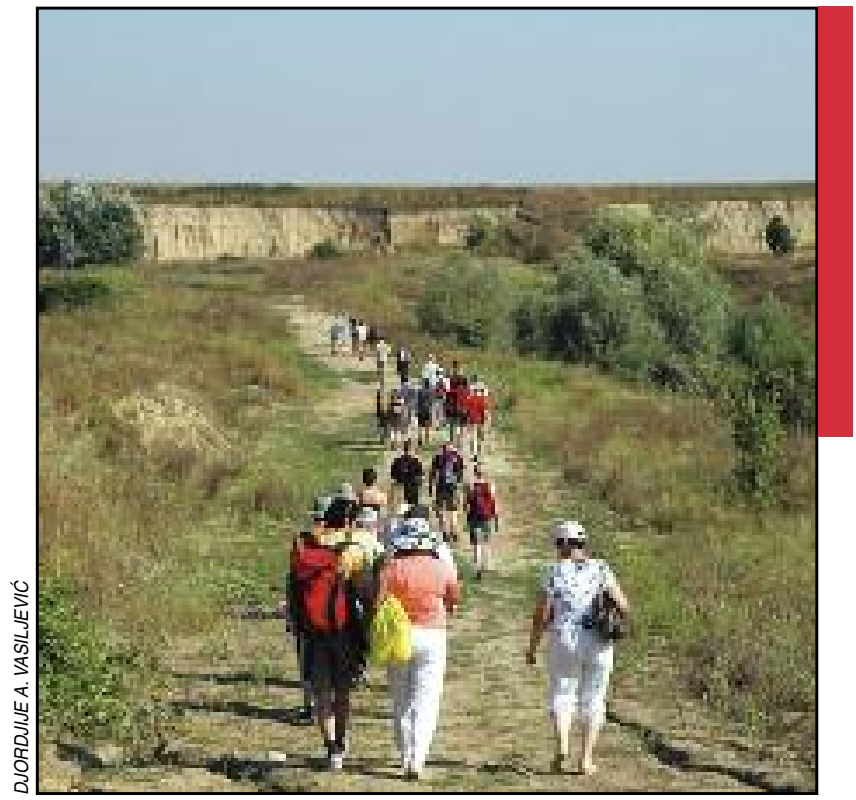

Picturesque loess landscape at the brickyard in Ruma; visited by eminent geoscientists and loess researchers from worldwide during LoessFest'09 Conference Fieldtrip 


\section{Loess towards (geo) tourism - proposed application on loess in Vojvodina region (north Serbia)}

DOI: $10.3986 / A G S 51305$

UDC: $913: 551.311 .3(497.113)$

55:338.483(497.113)

COBISS: 1.01

ABSTRACT: Loess-palaeosol sequences preserve the most important continental record of climatic and environmental changes during the Quaternary. As a significant element of global geodiversity and geoheritage, loess-palaeosol sequences could be used as resources for a contemporary trend in sustainable tourism geotourism. This form of tourism appreciates and promotes non-living nature (geodiversity) through its conservation and interpretation. This further leads to enhancing public awareness of these sites. In this study, we report on a proposal for establishing geotourism at the most important loess sites in the Vojvodina region.

KEY WORS: loess, palaeosol, geotourism, geoheritage, interpretation, Vojvodina, Serbia

The article was submitted for publication on May 19, 2011.

ADDRESSES:

Djordjije A. Vasiljević, M. Sc.

Department of Geography, Tourism and Hotel Management

Faculty of Sciences, University of Novi Sad

Trg Dositeja Obradovića 3, 21000 Novi Sad, Serbia

E-mail: geotrends@dgt.uns.ac.rs

Slobodan B. Marković, Ph. D.

Department of Geography, Tourism and Hotel Management

Faculty of Sciences, University of Novi Sad

Trg Dositeja Obradovića 3, 21000 Novi Sad, Serbia

E-mail: slobodan.markovic@dgt.uns.ac.rs

Thomas A. Hose, Ph. D.

Rockhounds Welcome!, Chalton

Bedfordshire, LU4 9UT, United Kingdom

E-mail: t.hose123@btinternet.com

Ian Smalley, Ph. D.

Giotto Loess Research Group, Waverley Materials Project

Nottingham Trent University, Nottingham NG1 4BU, UK

E-mail: ian.smalley@ntu.ac.uk

Ken O'Hara-Dhand, Ph. D.

Giotto Loess Research Group, Waverley Materials Project

Nottingham Trent University, Nottingham NG1 4BU, UK

E-mail: koharadhand@ntu.ac.uk

Biljana Basarin, M. Sc.

Department of Geography, Tourism and Hotel Management

Faculty of Sciences, University of Novi Sad

Trg Dositeja Obradovića 3, 21000 Novi Sad, Serbia

E-mail: biljana.basarin@gmail.com 
Tin Lukić, M. Sc.

Department of Geography, Tourism and Hotel Management Faculty of Sciences, University of Novi Sad

Trg Dositeja Obradovića 3, 21000 Novi Sad, Serbia

E-mail: lukic021@gmail.com

\section{Miroslav D. Vujičić}

Department of Geography, Tourism and Hotel Management Faculty of Sciences, University of Novi Sad

Trg Dositeja Obradovića 3, 21000 Novi Sad, Serbia

E-mail:miroslav.vujicic@dgt.uns.ac.rs

\section{Contents}

1 Introduction 394

2 Loess - the general story 394

3 Loess in the Vojvodina region 395

4 Conservation, promotion and potential loess geotourism sites in the Vojvodina region 397

5 Geotouristic interpretation of loess 400

6 Conclusion 402

7 Acknowledgement 403

8 References 403 


\section{Introduction}

The contemporary trend of nature protection has recently improved its approach to conservation with more intensive care of endangered and rare species. Unfortunately, this is mostly is with regards to protection of biodiversity (flora and fauna) which often marginalises components of so called non-living nature or geodiversity (Erhartič 2010). Considered as robust and endurable natural resources, elements of geodiversity are often degraded by human ignorance or due to their economic or functional values (Gray 2004, 2008). The most efficient way to conserve geodiversity is to raise (enhance) public awareness on its (scientific, aesthetic, educational, touristic, etc.) values through promotion and popular interpretation - geotourism (Hose, 1995). Many of these sites, formerly identified and attractive only for the scientific community, could be more widely recognised and appreciated. Hence, geotourism as recently redefined as »the promotion of geologic and geomorphic sites for their scientific and societal value to ensure their conservation for future use by academics, tourists and casual recreationalists " (Hose 2003, 2008) is a means to reach out to the public. Modern geotourism (Hose 1995; 2006; 2011) was conceived in the United Kingdom as a means to promote and provide some funding for geoconservation activities. It arose as a response to the significant loss of sites with geological ('geosites' sendsuo stricta) and geomorphological ('geomorphosites') interest. Whilst focussed in the early years of geotourism research on 'hard-rock' geosites, in recent years the loss of 'soft-rock' geomorphosites has been recognised as an equally major issue; this is particularly the case in eastern England (Hose, 2011) for 'soft rock' quarry geosites. The relatively ephemeral nature of quarries working Quaternary sands and gravels, compared with those working Mesozoic and Palaeozoic rocks (limestones, sandstones, and granitic and basaltic rocks) gives a very short time for their recognition, notification and conservation. Further, the scientific interest of many of them is actually enhanced by the extraction process that reveals relict geomorphological features in their three-dimensional splendour.

As a significant Quaternary palaeoclimatic and palaeoenvironmental archive on European land, loess-palaeosol sequences in the Vojvodina region represent important elements of geodiversity (Marković et al. 2008; 2011, Vasiljević et al. 2009; 2011). This study aims to present the potential of these sites to be interpreted and promoted as geotourism resources to a wider audience than Earth scientists. It will also provide certain proposals and possible further steps towards geotourism development of these loess localities.

\section{Loess - the general story}

Loess is windblown dust deposited over extensive areas in mid latitudes. Loess and loess-like sediments cover $10 \%$ of Earth land surfaces (Pecsi 1990, Heller and Evans 1995, Smalley et al. 2011). Main sequences of loess are found at plains (e.g. Pampean Plain, Russian Plain), plateaus (e.g. Chinese loess plateau) and along river basins (e.g. Danube Basin, middle Rhine Basin, Mississippi Basin, middle Yellow River Basin) as typical geographical zones for its deposition. Loess deposits have gained great importance in reconstruction of past climates ever since the pioneer work of Kukla (1977), An et al. (1977) and Heller and Liu (1982).

Chronologically, the formation of loess deposits is related to the glacial cycles in the Pleistocene. Loess dusts are transported and deposited by wind during glacial periods. During warmer (interglacial) periods, loess deposition is affected by various climatic conditions associated with higher temperature, higher precipitation, and increase of chemical and biological activity. Formerly mentioned processes resulted in the formation of soils. Loess-palaeosol sequences are indeed interesting geological formations which enclose the Earth's climate history over many glacial and interglacial cycles, or even geological ages. Loess deposits are interlayered with soil bodies, representing the shift from cold and dry to warm and wet climatic conditions (e.g. Kukla 1977, An et al. 1977, Pecsi 1990).

The most complete and thickest loess deposits are found in China, in the provinces of Shanxi, Shaanxi, and Gansu (Stevens et al. 2007, 2008). Dust deposition and the formation of continuous loess palaeosol sequences in China's Loess Plateau began $22 \mathrm{My}$ ago (Guo et al. 2002). The last 2.6 Ma were also recorded continuously, and in more detail than any other types of palaeoclimatic records available (sediments, ice, etc.), making it a fundamental archive for understanding the climatic history of Earth (e.g. Liu et al. 2005). This loess belt covers the whole Euro-Asian continent, spreading from the Atlantic to the Pacific coasts.

In Europe, loess and loess-like sediments cover almost 1/5 of the total surface of Europe and is thus a major sediment type as a soil parent material. Dust accumulation disseminates from the maritime areas 
of NW Europe, over Central Europe, to the Ukraine and the Russian plains (Haase et al. 2007). Much of the loess cover in Eastern and Central-Eastern Europe has been redeposited by the Danube River. Other areas of loess are associated with rivers such as the Po in Italy, the Rhine in Western Germany and the Rhone in France (Smalley 1995). The loess-palaeosol sequences situated in the Vojvodina region, North Serbia, represent the most detailed archive of climatic and environmental fluctuations during the Middle and Late Pleistocene on European continent (Marković et al. 2005a, 2006, 2007a, 2007b, 2008, 2009a, 2011).

The loess that covers large parts of the North American continent, from Alaska at the northwest to the Mid-continental North America has the thickest deposits of last-glacial loess in the world (Muhs and Bettis 2003, Roberts et al. 2003). Typical loess is not widespread in Australia, although there are limited occurrences of clay-rich aeolian deposits termed parna that some workers interpret as essentially clay-rich loess. However, more considerable loess deposits cover much of New Zealand, where it has been studied in great detail (Smalley 1995).

\section{Loess in the Vojvodina region}

The Vojvodina region is situated in the south-eastern part of the Carpathian (Pannonian) Basin, and encompasses the confluence area of the Danube, Sava, and Tisa rivers (Figure 1). This northern province of Serbia includes the most complete and the thickest loess-palaeosol sequences within Europe. Loess and loess like

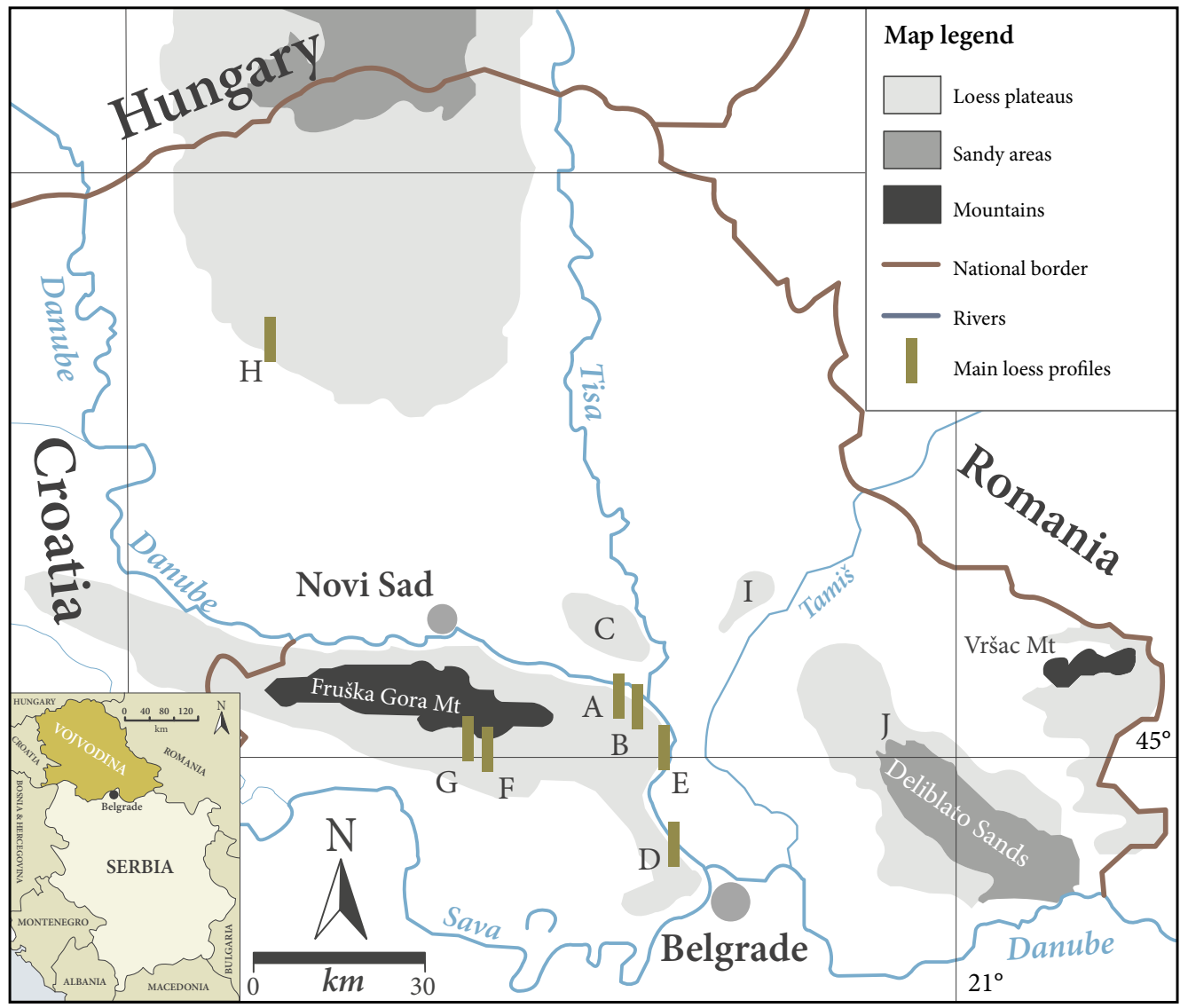

Figure 1. Distribution of the loess deposits and main geomorphologic features in the Vojvodina region; key loess sections are labeled by capital letters (after Marković etal. 2004, modified). 


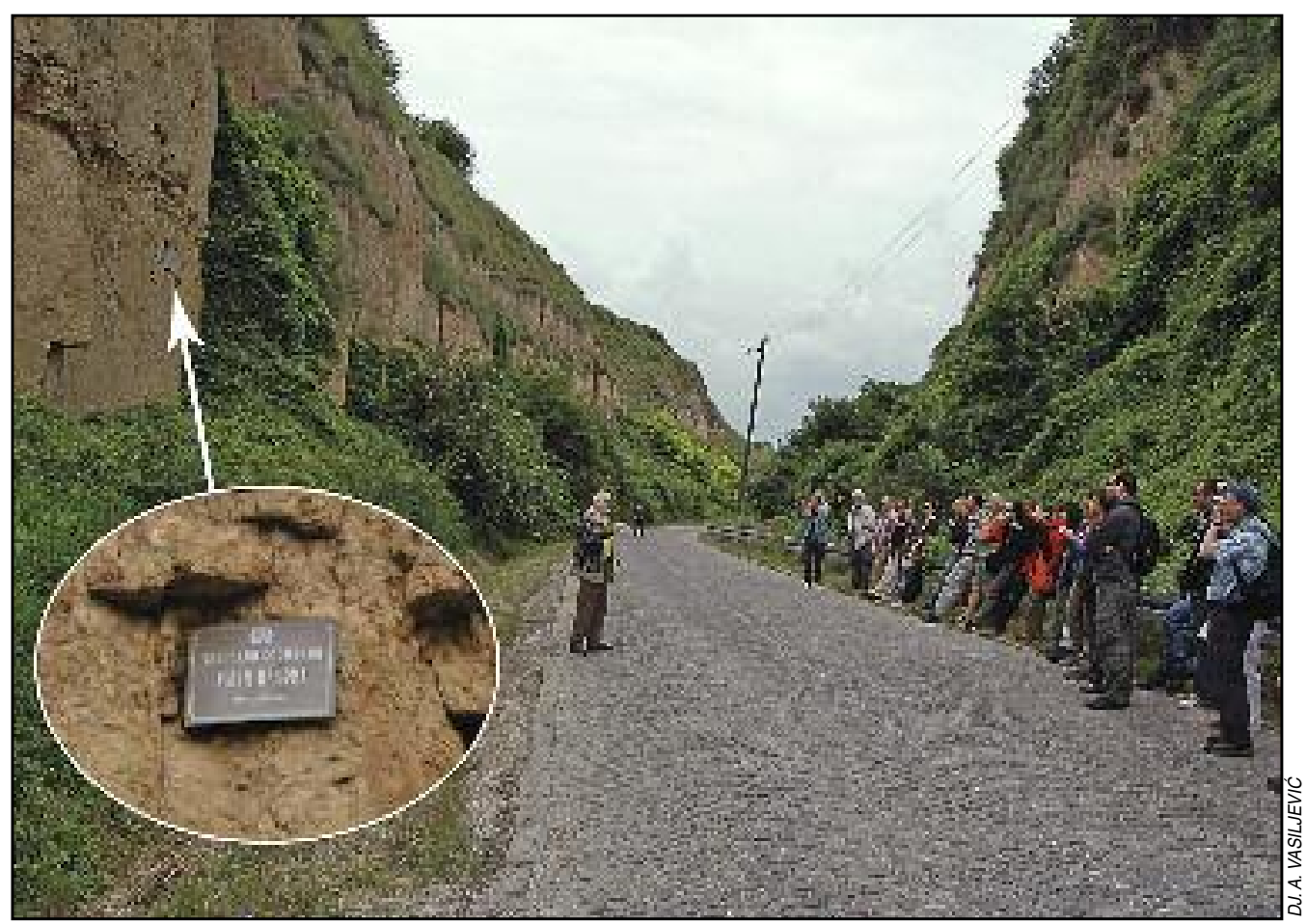

Figure 2. The loess profile in Stari Slankamen gorge (Monument of Nature since 1975) interpreted by lan Smalley during Geotrends 2010 conference field trip.

sediments cover more than $60 \%$ of the area and are preserved in six separate loess plateaus: Bačka, Srem, Tamiš, Banat, south-east Banat, and Titel Loess Plateau (Marković et al. 2008) (Figure 1).

Italian officer and scientist Luigi Ferdinando Marsigli gave the first scientific description of loess in Vojvodina at the end of the $17^{\text {th }}$ and beginning of the $18^{\text {th }}$ centuries. Noticeable loess- palaeosol exposures along the Danube river valley near Stari Slankamen, Titel and Petrovaradin were drawn by Marsigli in his outstanding six volume book Danubius Pannonico Mysicus (1726) (Marković et al. 2004, 2009b). It is evident that many sedimentological characteristics of loess-palaeosol sequences recognized by Marsigli remain valid to this day. Bearing in mind that since that time loess-palaeosol sequences have remained the object of numerous investigations it can be stated that in the Vojvodina region there exist sites which represent a detailed archive of climatic and environmental fluctuations over the last million or so years.

In comparison with other European loess-palaeosol sequences that were generally formed during the late Pleistocene and are characterised by smaller total thicknesses (e.g. Antoine et al. 2001, Vanderberghe etal. 1998, Rousseau et al. 2001, Shi et al. 2003), loess-palaeosol sequences in the Vojvodina region have a greater total thickness because they were formed during the last million years (Marković et al. 2005a, 2006, 2007a, 2007b, 2008 , 2009b; 2011). The multidisciplinary research approach that consists of detailed investigations of lithoand pedostratigraphy, magnetic and palaeomagnetic properties, grain size variations, geochemical analysis, amino acid racemisation measurements in fossil mollusc shelves as well as luminescence dating indicates that the loess deposits in the Vojvodina region are among the oldest and most complete loess-palaeosol sequences in Europe (Marković et al. 2004a, 2004b, 2005a, 2005b, 2006, 2007a, 2007b, 2008, 2009b, 2009c, 2011, Fuchs et al. 2008, Buggle et al. 2008, 2009, Antoine et al. 2009, Bokhorst et al. 2009, Bokhorst and Vandenberghe 2009, Zech et al. 2009, Schmidt et al. 2010, Ujvari et al. 2010, Stevens et al. 2011).

Additionally, due to their sedimentological characteristics, the significant thickness of loess-palaeosol sequences, and generally relatively dry climate in the Vojvodina region, many pseudokarst landforms have formed and then been preserved on loess covered terrain. These landforms are represented through loess 


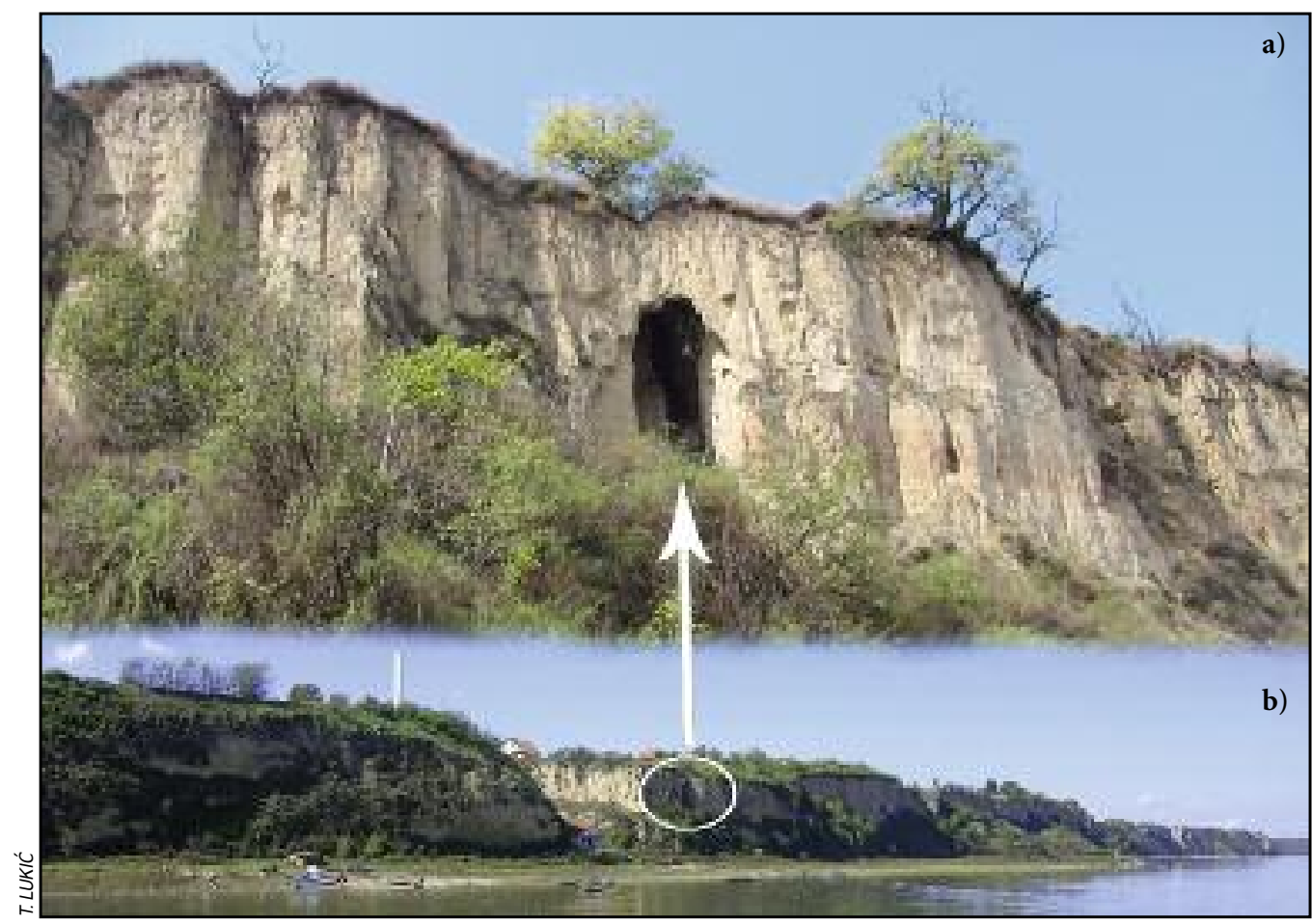

Figure 3. The loess profile near Surduk village: rare pseudokarst phenomenon - loess cave (a) and steep loess cliffs of Danube river bank (b).

caves (Figure 3a), wells, cliffs (Figure 3b), depressions, pyramids, gullies and natural bridges and can be regarded as morphological equivalents to collapse dolines or sinkholes formed in classical karst terrains (Lukić et al. 2009). In spite of their aesthetical attractiveness and great geomorphological diversity such sites have a limited lifespan due to their vulnerability to erosion (e.g. Zeeden et al. 2007, Lukić et al. 2009). Additionally, many multidisciplinary values of loess are proven through the palaeontological characteristics of loess sites; continuous researches have discovered Middle Pleistocene bear in Ruma (Ursus Deningeri) and mammoth in Crvenka, Ruma, and Petrovaradin (Mammuthus Primigenius) (Marković et al. 2006). Moreover, at the archaeological park Viminacium, situated over Upper Miocene soft brown coal layers, the mammoth skeleton (Mammuthus throgonterii) was found at 270 meters east of the Imperial Mausoleum, at a depth of 27 meters, in the sediments of the Morava paleodelte, across which lie loess layers (Lister and Stuart 2010). Continuous malacofauna investigations of loess sites have shown different environmental dynamics of the region from the rest of Europe articulated through a warmer and diverse climate, indicating a significant diversity of mosaic environments (Marković et al. 2006, 2007, 2008).

\section{Conservation, promotion and potential loess geotourism sites in the Vojvodina region}

Many years after Marsigli, during the 20th century, a great number of researches (and associated publications) have been conducted and produced by geologists and geomorphologists from the former Yugoslavia (e.g. Vladimir Laskarev, Branislav Bukurov, Miloš Zeremski, and especially Jelena Marković-Marjanović), whose work initiated the interest from many international scientists (J. Butrym, H. Maruszczak, A. Bronger, etc). This resulted in the first protected loess site in 1975 when the profile in 
Stari Slankamen gully (Figure 1A) was proclaimed a Monument of Nature. In spite of being the first and only protected geo-object of this kind in the former Yugoslavia, the only conservation phase accomplished so far is an information plate with a sign that it is under state protection. Though it does not possess any interpretive facility, at least no governmental and legal exploitation of the site has happened and it has been successfully preserved through more than three decades (Figure 2).

Contemporary loess research in Vojvodina dates from the late 1990s when the Loess Research Group from Novi Sad began its thorough investigations on the numerous loess sections of the area. This certainly provided the evidence and data of loess's scientific importance and conservation need. Subsequently, and according to formerly conducted research, the National Council for Geoheritage of Serbia identified several loess sections as proposed geoheritage sites (Karamata and Mijović 2005). This inventory was initiated at the recommendation of the ProGEO association and is based on the classification of geosites by Wimbledon (1996). Due to the geotectonic division of Serbia, the main loess sections were determined as geomorphologic aeolian sites (Bačka loess plateau, Banat loess plateau, Srem loess plateau) due to sediment deposition during their morphogenesis. The same division also identified certain loess profiles as palaeopedological sections of a periglacial area (Batajnica, Kalvarija at Titel loess plateau, Stari Slankamen).

There are numerous exposures of loess-palaeosol sequences in Vojvodina with the most important ones presented in this paper (Figure 1). The most significant is the loess profile "Čot « in Stari Slankamen village (Figures 1B and 5) that has been the object of investigation since the beginning of the 20th century. It is more than $40 \mathrm{~m}$ thick, with loess layers intercalated with 10 palaeosols (Figure 5a). It contains valuable palaeoclimatic and palaeoenvironmental records of the Middle and Late Pleistocene. This profile has been used for the development of the chronostratigraphic model of the loess-palaeosol sequences in Vojvodina introduced by Marković and Kukla (1999). The formation of the loess-palaeosol sequences began approximately one million years ago and was determined by detailed investigation of their palaeo-

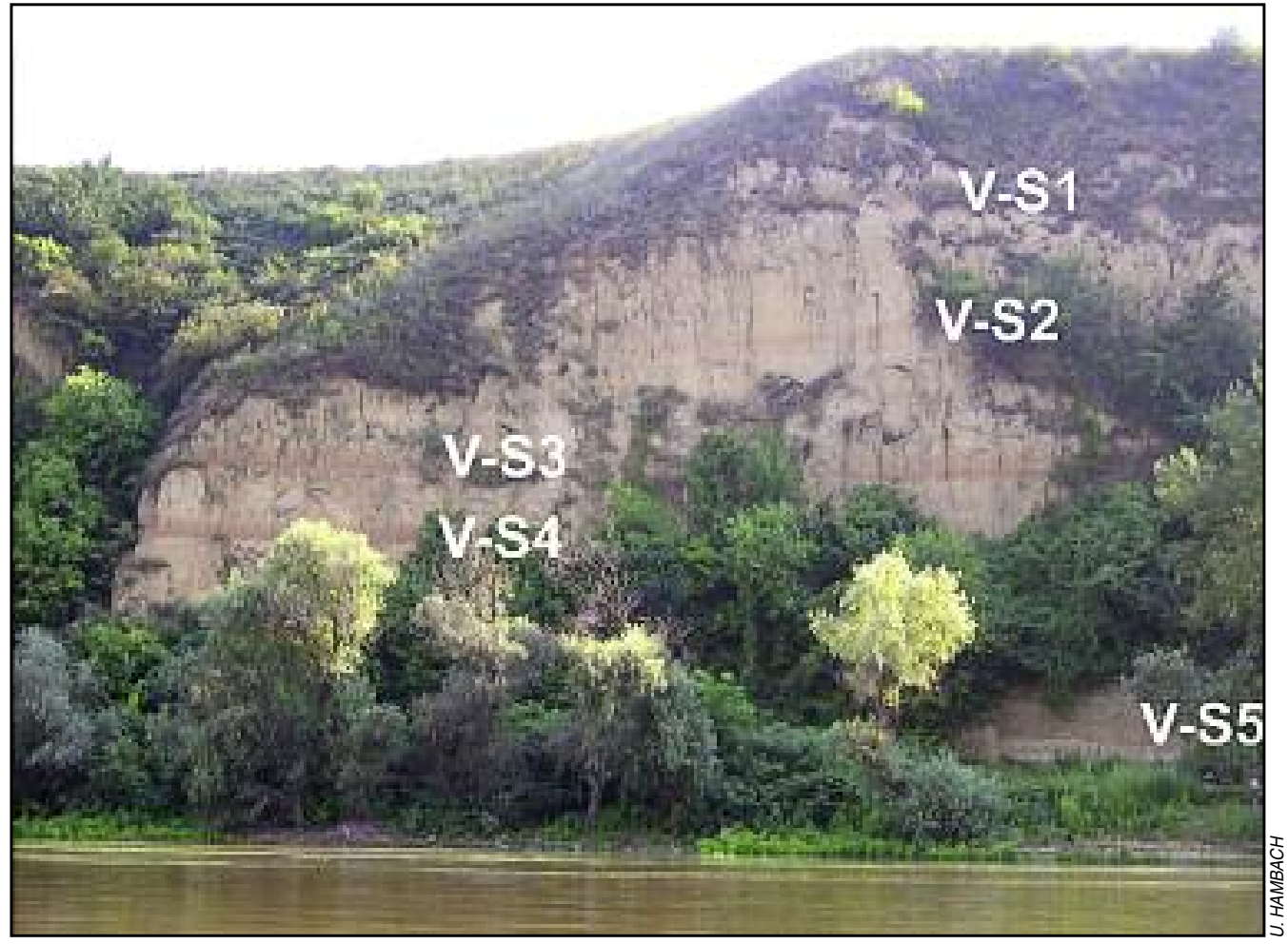

Figure 4. Titel Loess Plateau - potential Loess Geopark destination in Serbia. The most complete European contintal record of climatic and environmetal changes during the last five glacial-interglacial cycles. 
magnetic features (Marković et al. 2011). Therefore, this section possesses not only great regional but also global scientific importance due to its high grade scientific, educational and aesthetic values (Vujičić et al. this issue). In its close vicinity there is the previously mentioned (and currently the only law protected loess section in Serbia) profile "Surduk « in the gully between the villages of Novi Slankamen and Stari Slankamen. Besides its geological importance this locality also possesses an archaeological due to road remains from the Roman period.

Titel loess plateau is a unique geomorphologic feature, an isolated loess island at the south of Bačka region, in the confluence area of Tisa and Danube Rivers (Figure 1C). Thick loess deposits of between 35 and $55 \mathrm{~m}$ are intercalated by five main pedocomplexes likely deposited through the last five glacial/interglacial cycles. Steep loess cliffs expose several sections (profile in »Big gully« near Mošorin village, »Feudvar« section, »Dukatar « section (Figure 4), »Rogulić« gully, »Titel« old brickyard section, »Kalvarija « important section for understanding climatic and environmental change in the region during the Middle and Late Pleistocene. This isolated loess island and unique geomorphologic phenomenon, with a rich diversity of the loess landforms (e.g. loess »cave«, pyramid, gully, cliffs, etc), dominates its lower surroundings which makes it aesthetically and visually attractive. Additionally, sections such as »Feudvar « and »Kalvarija « possess great archaeological value (Bokhorst et al. 2009, Bokhorst and Vandenberghe 2009, Marković et al. 2005b).

Batajnica loess section (Figure 1D), situated $76 \mathrm{~km}$ south from Titel loess plateau, has been recognized as one of the most complete Middle and Late Pleistocene records in this region. More than $40 \mathrm{~m}$ thick loess-palaeosol succession represents an environmental transition from semi-humid subtropical environments, to temperate forest, and finally towards landscapes with typical steppe soils. The multiproxi record provides an important link between the classical Central European loess sites and the Central Asian and Chinese loess provinces during the last 620,000 years (Marković et al. 2009b).

Surduk loess section is located on the right bank of the Danube River (Figures 1E and $3 \mathrm{~b}$ ), around $30 \mathrm{~km}$ northwest of Belgrade. The exposure provides a $20 \mathrm{~m}$ thick pedosedimentary record of the last interglacial-glacial climatic cycle (Upper Pleistocene) (Fuchs et al. 2008, Antoine et al. 2009). The loess cliffs on the Danube River bank near the village of Surduk preserve both a unique archive of Quaternary climate change, and also exhibit diverse and short-lived landforms associated with the erosion of the deposits. One such landform is a very rare type of pseudokarst feature in the Vojvodina region, a loess cave (Lukić et al. 2009) (Figure 3a). Also, the attractiveness of the site led to the locality being chosen by director Emir Kusturica as the main setting of his film »Black Cat, White Cat «, awarded the Silver Lion for Best Direction at the Venice Film Festival (Lukić et al. 2010) in 1998.

Two important loess sections of Srem loess plateau are located on the southern slopes of Fruška Gora Mountain. The first one is the Ruma loess section (Figure 1F) at the excavation area of the local brickyard (Front page photo). The Ruma loess section preserves palaeoclimatic and palaeoecological evidence of environmental fluctuations during the last 350,000 years. During the investigation remains of the large Pleistocene mammals Ursus deningeri and Mamuthus primigenius were excavated (Marković etal., 2004a; 2006). The second loess section is located also at the brickyard, in Irig village, $11 \mathrm{~km}$ north from Ruma (Figure 1G). Malacological analysis indicated that during the last glacial cycle stable, dry and relatively warm glacial climate dominated, compared with other central European loess localities. Furthermore, these data suggest that the southern slope of Fruška Gora was a refugium for warm-loving and xerophilus mollusc species during the glacial cycle of the Late Pleistocene (Marković et al. 2007).

Recently, initial research results of loess-palaeosol sequences of Bačka loess plateau (Figure 1H) indicate the great importance of investigated sections at Crvenka section (Zech et al. 2009, Stevens et al. 2011). Furthermore, it is expected that, in the near future and with further research, also the loess sections at Tamiš (Figure 1I) and Banat (Figure 1J) loess plateaus could prove to be of great significance. The Banat loess plateau, together with Deliblato sandy sequence, represents the spectacular spatial and temporal diversity of aeolian depositional dynamics unique in Europe.

In spite of the formerly presented evidence of these loess geosites' (mainly scientific) importance, loess-palaeosol sequences in Vojvodina do not get as much attention from the general public as the geoconservation community would like; they are ignored and degraded by various factors (e.g. Vasiljevićet al. 2011). Similarly, the most significant European loess profiles are (or were formerly) exposed in brickyards, such as Nussloch, Kesselt, Dolní Věstonice (Figure 6a), Červeny Kopec, Krems, Paks, Basaharc, Sütto, Madaras, Katymár, Viatovo and Mircea Voda. One of the key loess sites for investigating climate variations of the Middle and Late Pleistocene of central Europe, Červeny Kopec near Brno in the Czech Republic, which 
was used to correlate terrestrial sequences with marine sediments, was obliterated in the course of its exploitation for construction material. Consequently, only a few palaeo-pedocomplexes of the 'classic' loess profile survive in Europe and their conservation must now be a priority.

\section{Geotouristic interpretation of loess}

Clearly, geotourism depends for its success upon identifying and promoting its physical basis (especially geosites, geomorphosites and museum collections), knowing and understanding its existing and potential user base and developing and promoting effective interpretative materials, that is implementing environmental interpretation programmes that involve: »... a range of activities carried out by managers of countryside and heritage sites. It can be defined as: 'the art of explaining the meaning and significance of sites visited by the public'." (Badman 1994, 429). It has been suggested by several authors of interpretation texts (e.g. Sharpe 1982, 495) that interpretation has three projected outcomes, to:

- assist visitors to appreciate site significance;

- aid in site management;

- promote understanding of the site agency's policies.

Different authors ascribe different priorities to these outcomes. For geotourism, the first two outcomes are significant and the latter only assumes importance insofar as it often inhibits the effectiveness of the other two; that is, interpretative provision is sometimes is more focussed on establishing agency territoriality than with communicating site value and significance. Interpretation is not so much a science as more of an art because although: »... it draws on scientific analysis and materials and often uses technology to convey its message ... it is an 'art' ... calls for flair, imagination, creation ... It is about revealing the essence of a place ... the prime measure of success is whether the significance of the site has been conveyed to the visitor." (Phillips 1989, 123-124).

Dingwall et al. (2005) proposed 13 geothemes for geological World Heritage sites with the addition that some sites fall into more than one theme. According to Vasiljević et al (2011), by these categories, loess-palaeosol sequences could be assorted as stratigraphic sites - indicator of a succession of interglacial environmental changes - from semi-humid subtropical environments, to temperate forest, and finally towards landscapes with typical steppe soils; ice age sites - interpretation of Pleistocene glacial and interglacial periods according to preserved palaeosol succession at the loess exposures which demonstrates unique opportunity for recognising drastic climatic and environmental changes; and arid and semi-arid landforms and landscapes - comparison of investigated palaeosols with recent soils on a global basis; which also prove both their great scientific importance and landform diversity.

The scientific value of loess-palaeosol sequences in the Vojvodina region is, undoubtedly, its greatest significance for the development of niche tourism (Hose, 2005). Both experts (dedicated geotourists) and non-specialists (casual geotourists) should be allured by the educational and interpretative components of loess-palaeosol sequences. This can be achieved by interpretation, which is essential provision for public, especially tourists', understanding and experience of the places they visit. For this particular purpose it is necessary to explain geological heritage and to 'bring it to life' (Vasiljević et al. 2011).

Most of the loess profiles are lacking very important aesthetic values (brickyards) (e.g. Ruma (Front page photo), Irig, Crvenka) or are situated in remote areas and relatively inaccessible (steep cliffs on river banks). Therefore interpretation should be broadened to cover all aspects of loess research encompassing the whole ice-age period with interesting stories not just with geological background, but life on Earth in general. Answers to important questions such as - what is loess, why is it important, and why in Vojvodina, coupled with an account of the history and techniques of loess research, would be given to non-specialists in an entertaining and interesting manner, sometimes termed 'edutainment'. This could also make an ideal introduction to further presentations on loess deposits. Besides the general scientific meaning of loess-palaeosol sequences it is necessary to include various natural and social academic disciplines, such as anthropology, archaeology, biology, ecology, ethnology, history, palaeontology, etc. This multidisciplinary approach, combined with modern technology (interactive panels, presentations, audio-visual effects), should improve visitor's knowledge and raise public awareness of the importance of protection and conservation of natural heritage. Many of these methods could be utilised at loess geosites and some of their 


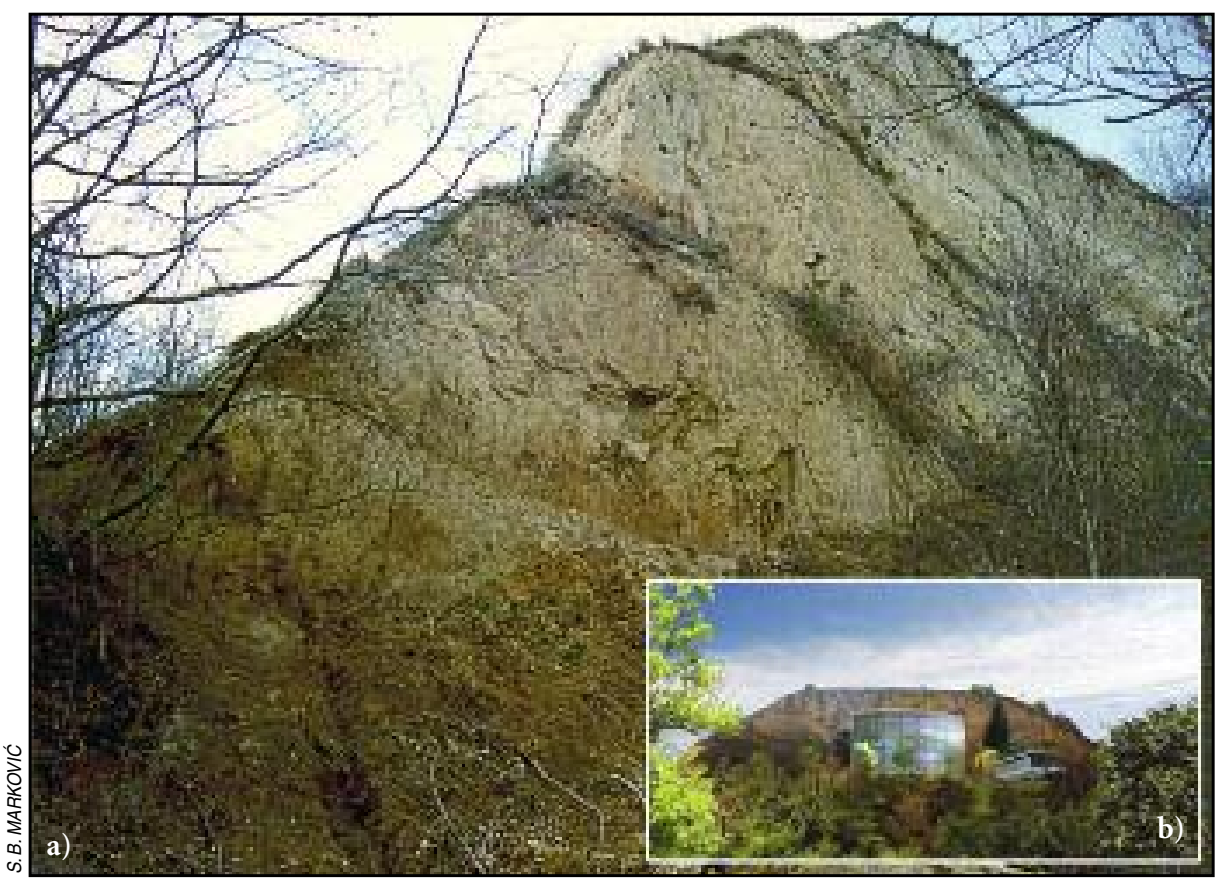

Figure 5. The most significant loess section in the Vojvodina region: a) Profile Čot near Stari Slankamen village and b) Proposed Loessland Museum facility.

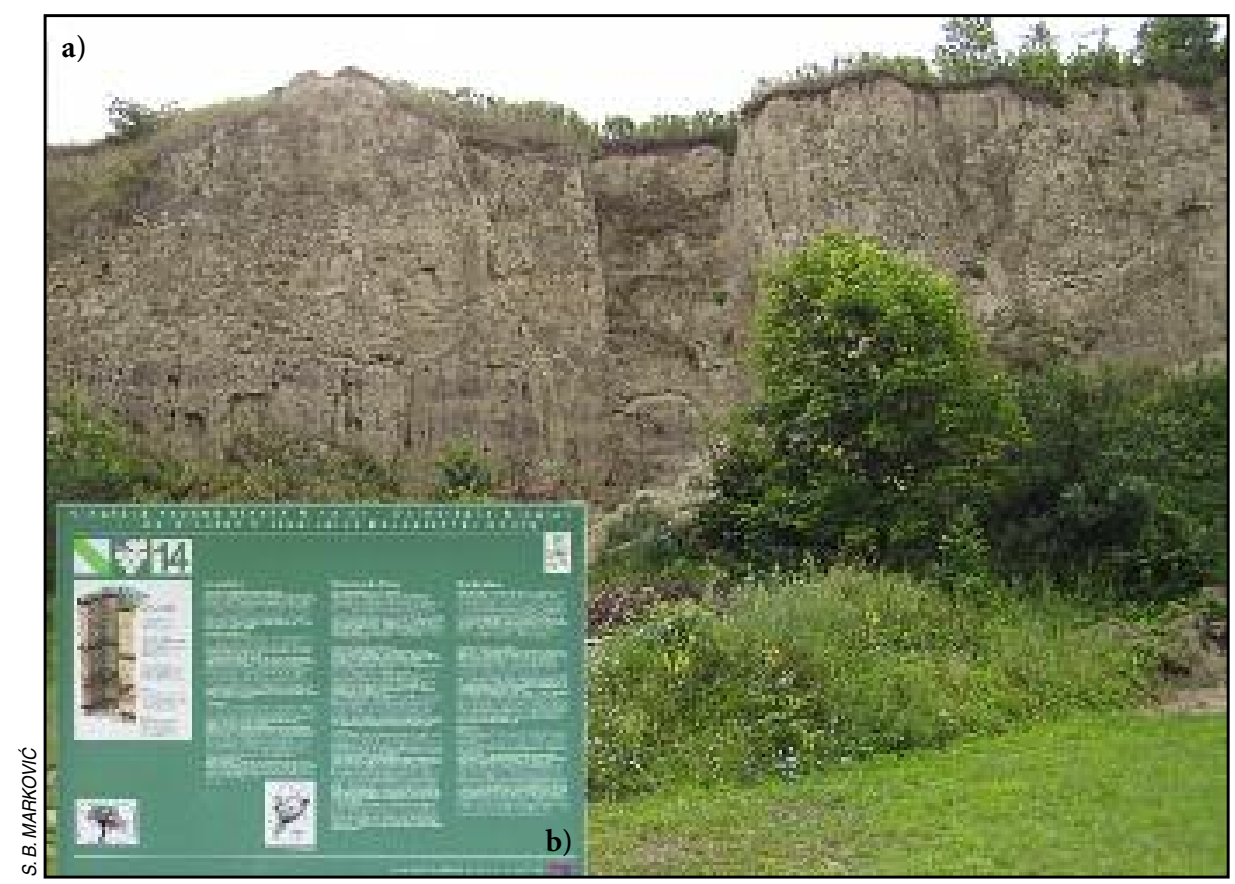

Figure 6. a) Loess profile in the brickyard of Dolní Věstonice (Czech Republic) - important for both geological and archaeological findings; $b$ ) Interpreted in situ by trilingual panel. 
possible implementations could include interpretive panels (most common) and guided field excursions, and activities such as populist fieldwork and sampling, and educational laboratories (Vasiljević et al. 2011).

The first idea for the loess geotourism destination in the Vojvodina region was presented in Marković et al. (2005b) that reports the plans of certain institutions to establish a Loess Geopark in Vojvodina, with Titel loess plateau as its central and vital part. This geopark would have a dispersive characteristic (Marković et al. 2005b, Vasiljević et al., 2009), following the dissemination of loess deposits in this region.

Afterwards, there have been some intentions to even propose Titel loess plateau as an individual geopark. Although Titel loess plateau possesses significance and attractiveness, it does not cover »... large enough surface area for it to serve local economic and cultural development ... «(Global Geoparks Network, 2008). This locality has already been proposed by the Institute for Nature Conservation of Serbia as a Natural Reserve, with no conservational effects though. Significant loess profiles (e.g. Čot in Stari Slankamen, those near Batajnica and Surduk villages) should be proclaimed as Monuments of Nature, while loess sections at Srem loess plateau (Ruma and Irig brickyard), could be affiliated to Fruška Gora geopark, the project initiated by the Provincial Secretariat for Energy and Mineral Resources of Vojvodina. These, individually managed loess sites require less investments and more achievable executive tools (management, organisation, supervision, etc.). Instead of creating a holistic loess geopark in Vojvodina, these individual sites could be connected by thematic routes, that would certainly additionally broaden the (geo)touristic offer of the area.

The first, to some extent, practical attempt to create a loess geotourism locality is the so called »Loessland « project at the Čot loess section in Stari Slankamen village (Figure 5b). Due to many decades of research that showed the extraordinary importance of the profile, the Municipality of Inđija decided to initiate the attractive and modern thematic museum, the »Loessland « project. The museum would be a modern building, with much glass, with several levels leaning on the loess profile. This would give the opportunity for visitors to see and access loess-paleosol sequences that were formed during the last million years. Numerous interesting exhibitions would be displayed in various thematic parts, introducing the secrets of the Ice Ages, geology, geography and many other related topics to a wide audience. The special emphasis would be on applying modern audio-video equipment (PDA - Personal Digital Assistant) in order to make any presentation as attractive and interesting as possible. Other additional facilities would include a tourist information centre, souvenir shop, and themed café/restaurant, providing the necessary base for tourism development (Vasiljević et al. 2011).

The implementation of geotourism schemes can extend the timing and nature of tourism (Hose 1995) which is, with the increasing costs and complexity of its specific and generic infrastructural requirements, necessary in order to recoup the financial investment in the shorter timeframes demanded these days by investors (whether governmental or commercial) and society at large.

\section{Conclusion}

The loess sediments of the Vojvodina region generally possess great scientific value as is well established by eminent national and international scientific communities, especially the geological and geomorphological, but in terms of their own criteria. Hence, their communications, such as academic papers, address only the needs of a rather small specialist audience. Their attempts to present any of their scientific findings are, following the findings of geotourism research that found much of the early interpretative provision at geosites by specialists was too scientific in content and written in a style with limited appeal (Hose 1997), is likely to be of limited communicative competence. Indeed, such attempts by the scientific community to reach out to a broader non-scientific audience are often mistakenly dismissed amongst peers as mere 'dumbing down'!

The most suitable initial solution would be for the scientific community to liaise with the environmental and landscape interpretive communities to produce informational and interpretative media for the public. A possible first step would be the provision of temporary interpretive panels (Figure 6b) as they require no big investments or considerable infrastructural projects, but they do require updating and maintenance. Modern computer software publishing packages, large format digital printers and thermal laminating systems provide a cost-effective means (Hose 2000, 145) for their rapid production and replacement. Such panels also have the advantage that they are suitable, unlike publications that have to be distributed 
from some point such as a visitor or tourist information centre, for casual visitors; they can be something they stumble across, providing new meanings, on their visit to a site that they might be visiting mainly for social and recreational purposes.

However, a disadvantage of these is that they are generally, because of space limitations, only really suitable for single language presentations if detail information is to be provided. There are good examples were dual language publications such as leaflets, as in Wales (Burek 2005), have been necessarily produced. For those who perhaps would like to plan their visit in advance then it might well be that web-based print on demand materials could be made available; the advantage of these is that they can most readily be prepared in various language versions and are thus suitable for overseas visitors. Of course, at dedicated visitor centres much more in terms of information coverage and activities, and even meeting the needs of local and international visitors, is possible. However their design, construction and fitting out with exhibitions are a major and costly undertaking; there is also the danger that they might become more of an attraction in themselves than the actual geosite they are supposed to promote.

Future undertakings, such as »Loessland «, present a great leap forward in the field of geoconservation and geotourism. Current focus should be on development of geotouristic infrastructure in term of site-interpretative panels, marking tracks, training courses and other educational activities that lead to promotion of geoconservation and geotourism in general. Apparently, in addition to all the other complementary natural and cultural values of the investigated area, it is evident that this site presents a timely perspective and sustainable (geo) touristic destination (Vujičić et al. this issue).

Geoconservation is a dynamic approach to the preservation and maintenance of geosites and geomorphosites; that is, it accepts that some change is both inevitable and can be a means of ensuring continuing access to geological and geomorphological features (Hose, 1998). Therefore it is also important to understand the significance of implementation and execution of geoconservation measures and their integration within tourism promotion. In this way these two key elements would lead to greater expansion of geotourism in general. This activity presents the first necessary step towards loess (geo) tourism not only on a regional but on a global basis as well.

\section{Acknowledgement}

This work is supported by the Ministry of Science and Technological Development, Republic of Serbia (grant 176020).

\section{References}

An, Z. S., Wang, J., Li, H. 1977: Palaeomagnetic research of the Lochuan loess section (in Chinese with English abstract). Geochimica 4. China.

Antoine, P., Rousseau, D. D., Zöller, L., Lang, A, Munaut, A. V., Hatte, C., Fontugne, M. 2001: High-resolution record of the last Interglacial-glacial cycle in the Nussloch loess-palaeosol sequences, Upper Rhine Area, Germany. Quaternary International 76/77. Amsterdam. DOI:10.1016/S1040-6182(00)00104-X Antoine, P., Rousseau, D. D., Fuchs, M., Hatte, C., Gautier, C., Marković, S. B., Jovanović, M., Gaudenyi, T., Moine, O., Rossignol, J. 2009: High resolution record of the last climatic cycle in the Southern Carpathian basin (Surduk, Vojvodina, Serbia). Quaternary International 198/1-2. Amsterdam. DOI:10.1016/j.quaint.2008.12.008

Badman, T. 1994: Interpreting earth science sites for the public. Geological and Landscape Conservation. London.

Bokhorst, M., Beets, C. J., Marković, S. B., Gerasimenko, N. P., Matviishina, Z. N., Frechen, M. 2009: Pedochemical climate proxies in Late Pleistocene Serbian-Ukranian loess sequences. Quaternary International 198/1-2. Amsterdam. DOI:10.1016/j.quaint.2008.09.003

Bokhorst M. P., Vandenberghe, J. 2009: Validation of wiggle matching using a multi-proxy approach and its palaeoclimatic significance. Journal of Quaternary Science 24. Chichester. DOI:10.1002/jqs.1271

Buggle, B., Glaser, B., Zöller, L., Hambach,U., Marković, S., Glaser, I., Gerasimenko, N. 2008: Geochemical characterization and origin of Southeastern and Eastern European loesses (Serbia, Romania, Ukraine). Quaternary Science Reviews 27/9-10. Amsterdam. DOI:10.1016/j.quascirev.2008.01.018 
Buggle, B., Hambach, U., Glaser, B., Gerasimenko, N., Marković, S. B., Glaser, I., Zöller, L. 2009: Stratigraphy and spatial and temporal palaeoclimatic trends in Southeastern/East European loess palaeosol sequences. Quaternary International 196/1-2. Amsterdam. DOI:10.1016/j.quaint.2008.07.013

Burek, C. V. 2005: Stimulating Public Interest in our Urban Environment in Wales. Stone in Wales, Materials, Heritage and Conservation. Cardiff.

Burek, C. V., Prosser, C. D. 2008: The history of geoconservation: an introduction. London.

Butrym, J., Maruszcak, H., Zeremski, M. 1991: Thermoluminescence stratigraphy of Danubian loess in Belgrade environs. Annales B 46. Lublin.

Dingwall, P., Weighell, T., and Badman, T. 2005: Geological world heritage: A global framework. Global Theme Study of World Heritage Natural Sites: Protected Area Programme. Switzerland.

Erhartič, B. 2010: Geomosphosite assessment Acta geographica Slovenica 50-2. Ljubljana. DOI: 10.3986/AGS50206

Fuchs, M., Rousseau, D. D., Antoine, P., Hatte, C., Gauthier, C., Marković, S., Zöller, L. 2008: Chronology of the last climatic cycle (Upper Pleistocene) of the Surduk loess sequence, Vojvodina, Serbia. Boreas 37/1. Oslo. DOI: 10.1111/j.1502-3885.2007.00012.x

Global Geoparks Network. 2008: Guidelines and Criteria for National Geoparks seeking UNESCO's assistance to join the Global Geoparks Network. United Nations Educational, Scientific and Cultural Organization. Paris. Internet: http://www.globalgeopark.org/Portals/1/documents/2008GGN-(guidelines)uneendorsed.pdf) (12.3.2011).

Gray, M., 2004: Geodiversity - valuing and conserving abiotic nature. New York.

Gray, M., 2008: Geodiversity: developing the paradigm. Proceedings of the Geologists' Association 119/3-4. Amsterdam. DOI: 10.1016/S0016-7878(08)80307-0

Guo, Z., Ruddiman, W. F., Hao, Q., Wu, H., Qiao, Y., Zhu, R., Peng, S., Wei, J., Yuan, B., Liu, T. 2002: Onset of Asian desertification by $22 \mathrm{Myr}$ ago inferred from loess deposits in China. Nature 416. London.

Haase, D., Fink, J., Haase, G., Ruske, R., Pecsi, M., Richter, H., Altermann, M., Jäger, K. D. 2007: Loess in Europe - its spatial distribution based on a European Loess Map, scale 1:2,500,000. Quaternary Science Reviews 26/9-10. Amsterdam. DOI: 10.1016/j.quascirev.2007.02.003

Heller, F., Liu, T. S. 1982: Magnetostratigraphical dating of loess deposits in China, Nature 300. London.

Heller, F., Evans, M. E. 1995: Loess magnetism. Reviews of Geophysics 33-2. Washington.

Hose, T. A. 1995: Selling the Story of Britain's Stone, Environmental Interpretation 10-2. London.

Hose, T.A. 1997: Geotourism - Selling the earth to Europe. Engineering geology and the environment. Rotterdam.

Hose, T. A. 1998: Mountains of fire from the present to the past - or effectively communicating the wonder of geology to tourists, Geologica Balcanica 28-3.

Hose, T. A. 2000: European Geotourism - Geological Interpretation and Geoconservation Promotion for Tourists. Geological Heritage: Its conservation and management. Madrid.

Hose, T. A. 2003: Geotourism in England: A Two-Region Case Study Analysis. Ph. D. thesis. University of Birmingham. Birmingham.

Hose, T. A. 2005: Geo-Tourism - Appreciating the deep time of landscapes. Niche tourism; contemporary issues, trends and cases. Oxford.

Hose T. A. 2005. Geo-tourism - appreciating the deep time of landscapes. Niche Tourism: contemporary issues, trends and cases. Oxford.

Hose T. A. 2006. Leading the Field: A Contextual Analysis of the Field-Excursion and the Field-Guide in England. Critical issues in leisure and tourism education conference: Current trends and developments in pedgogy and research. High Wycombe.

Hose, T. A. 2007. Geoconservation versus geo-exploitation and the emergence of modern geotourism. Geo-Pomerania Szczecin 2007 joint meeting PTG7 DGG: Geology cross-bordering the Western and Eastern European Platform. Szczecin.

Hose T. A. 2008. Towards a history of Geotourism: definitions, antecedents and the future. The History of Geoconservation 300. London.

Hose, T. A. 2011: The English Origins of Geotourism (as a Vehicle for Geoconservation) and Their Relevance to Current Studies. Acta Geographica Slovenica 51-1. Ljubljana. DOI: 10.3986/AGS51101

Jovanović, M., Zvizdić, O. 2009: Geonasleđe lesnih profila u Vojvodini. Novi Sad.

Karamata, S., Mijović, D. 2005: Inventory of the geological heritage sites of Serbia. Proceedings of $2^{\text {nd }}$ conference on the geoheritage of Serbia. Belgrade. 
Kukla, G. 1977: Pleistocene land-sea correlations 1. Europe. Earth Science Reviews 13. Amsterdam. DOI: $10.1016 / 0012-8252(77) 90125-8$

Lister, A. M., Stuart, A. J. 2010: The West Runton Freshwater Bed and the West Runton Mammoth. Quaternary International 288/1-2. Amsterdam. DOI: 10.1016/j.quaint.2010.07.032

Liu, Q., Banerjee, S. K., Jackson, M. J., Deng, C., Pan, Y., Zhu, R. 2005: Inter-profile correlation of the Chinese loess/palaeosol sequences during Marine Oxygen Isotope Stage 5 and indications of pedogenesis. Quaternary Science Reviews 24. Amsterdam. DOI: 10.1016/j.quascirev.2004.07.021

Lukić, T., Marković, S. B., Stevens, T., Vasiljević, Dj. A., Machalett, B., Milojković, N., Basarin, B., Obreht, I. 2009: The loess cave near the village of Surduk-an unusual pseudokarst landform in the loess of Vojvodina, Serbia. Acta Carsologica 38/2-3. Ljubljana.

Lukić, T., Marković, S. B., Stevens, T., Vasiljević, Dj. A., Basarin, B., Milojković, N., Lazić, L., Obreht, I., Đorđević, J. 2010: Importance of geoconservation of the loess »cave« in Surduk village as rare pseudokarst landform in the loess-paleosol sequences of Vojvodina (N Serbia). International conference on Geoheritage and Geotourism Research Geotrends 10. Novi Sad.

Marković, S. B., Kukla, J. 1999: Magnetic susceptibility and grain size records in the Stari Slankamen loess section (Vojvodina, Yugoslavia). Loessfest '99. Bonn/Heidelberg.

Marković, S. B., Kostić, N., Oches, E. A. 2004: Palaeosols in the Ruma loess section. Revista Mexicana de Ciencias Geologicas 21-1. Mexico City.

Marković, S. B., McCoy, W. D., Oches, E. A., Savić, S., Gaudenyi, T., Jovanović, M., Stevens, T., Walther, R., Ivanišević, P., Galović, Z. 2005a: Palaeoclimate record in the Late Pleistocene loess-palaeosol sequence at Petrovaradin Brickyard (Vojvodina, Serbia). Geologica Carpathica 56-6. Bratislava.

Marković, S. B., Jovanović, M., Mijović, D., Bokhorst, M., Vandenberghe, J. Oches, E. A., Hambach U., Zoeller, L., Gaudenyi, T., Kovačev, N., Boganović, Ž., Savić, S., Bojanić, D., Milojković, N. 2005b: Titel loess plateau - geopark. Proceedings of $2^{\text {nd }}$ Conference on the geoheritage of Serbia. Belgrade.

Marković, S. B., Oches, E., Sümegi, P., Jovanović, M., Gaudenyi, T. 2006: An introduction to the Upper and Middle Pleistocene loess-palaeosol sequences of Ruma section (Vojvodina, Serbia). Quaternary International 149-1. Amsterdam. DOI: 10.1016/j.quaint.2005.11.020

Marković, S. B., Hambach, U., Oches, E. A., McCoy, W. D., Zoeler, L., Jovanović, M. 2007a: 850 Millennia of paleoclimatic history recorded in the loess sequences of Vojvodina region, Serbia, Quaternary International 167/168. Amsterdam. DOI: 10.1016/j.quaint.2007.04.001

Marković, S. B., Oches, E. A., McCoy, W.D., Gaudenyi, T., Frechen, M. 2007b: Malacological and sedimentological evidence for "warm« glacial climate from the Irig loess sequence (Vojvodina, Serbia). Geophysics, Geochemistry and Geosystems 8. DOI: 10.1029/2006GC001565.

Marković, S. B., Bokhorst, M, Vandenberghe, J., Oches, E. A., Zöller, L., McCoy, W.D., Gaudenyi, T., Jovanović, M., Hambach, U., Machalett, B. 2008: Late Pleistocene loess-paleosol sequences in the Vojvodina region, North Serbia. Journal of Quaternary Science 23/1. Chichester. DOI: 10.1002/jqs.1124

Marković, S. B., Hambach, U., Catto, N., Jovanović, M., Buggle, B., Machalett, B., Zöller, L., Glaser, B., Frechen, M. 2009a: The middle and late Pleistocene loess-palaeosol sequences at Batajnica, Vojvodina, Serbia. Quaternary International 198/1-2. Amsterdam. DOI: 10.1016/j.quaint.2008.12.004

Marković, S. B., Smalley, I., Hambach, U., Antoine, P. 2009b: Loess in the Danube region and surrounding loess provinces: The Marsigli memorial volume. Quaternary International 198/1-2. Amsterdam. DOI: 10.1016/j.quaint.2009.02.001

Marković, S. B., Hambach, U., Stevens, T., Machalett, B., Kukla, G. J., Oches, E. A., McCoy, W. D., Buggle, B. Zöller, L., Lukić, T., Basarin, B. 2009c: The Last Million Years Recorded at the Loess- Palaeosol Sequences in the Vojvodina Region, Serbia, Milutin Milankovitch 130th Anniversary Symposium: Climate Change at the Eve of the Second Decade of the Century. Belgrade.

Marković, S. B., Hambach, U., Stevens, T., Kukla, G. J., Heller, F., William D. McCoy, W. D., Oches, E. A., Buggle, B., Zöller, L. 2011: The last million years recorded at the Stari Slankamen loess-palaeosol sequence: revised chronostratigraphy and long-term environmental trends. Quaternary Science Reviews 30/9-10. Amsterdam. DOI: 10.1016/j.quascirev.2011.02.004

Muhs, D. R., Bettis E. A. 2003: Quaternary loess-paleosol sequences as examples of climate-driven sedimentary extremes. Geological Society of America Special Paper 370. Boulder.

Phillips, A. 1989: Interpreting the Countryside and the Natural Environment. Heritage Interpretation Volume 1 - The Natural and Built Environment. London. 
Pecsi, M. 1990: Loess is not just the accumulation of dust. Quaternary International 7/8. Amsterdam. DOI: $10.1016 / 1040-6182(90) 90034-2$

Roberts, H. M., Muhs, D. R., Wintle, A. G., Duller, G. A. T., Bettis, A. E. 2003: Unprecedented last-glacial mass accumulation rates determined by luminescence dating of loess from western Nebraska. Quaternary Research 59. San Diego.

Rousseau, D. D., Gerasimenko, N., Matvviishina, Z. and Kukla, G. J. 2001: Late Pleistocene Environments of the Central Ukraine. Quaternary Research 56-3. San Diego. DOI: 10.1006/qres.2001.2270

Schmidt, E. D., Machalett, B., Marković, S. B., Tsukamoto, S., Frechen, M. 2010: Luminescence chronology of the upper part of the Stari Slankamen loess sequence (Vojvodina, Serbia). Quaternary Geochonology 5/2-3. Amsterdam. DOI: 10.1016/j.quageo.2009.09.006

Sharpe, G. W. 1982: Interpreting the Environment. New York.

Shi, C., Zhu, R., Glass, B. P., Liu, Q., Zeman, A., Suchy, V. 2003: Climate variations since the last interglacial recorded in Czech loess. Geophysical Research Letters 30-11. Washington. DOI:10.1029/2003GL017251.

Smalley, I. J. 1995: Making the material: the formation of silt-sized primary mineral particles for loess deposits. Quaternary Science Reviews 14/7-8. Amsterdam. DOI: 10.1016/0277-3791(95)00046-1

Smalley, I. J., Marković, S. B., Svirčev, Z. 2011: Loess is [almost totally formed by] the accumulation of dust. Quaternary International 240/1-2. Amsterdam. DOI: 10.1016/j.quaint.2010.07.011

Stevens, T., Thomas, D. S. G., Armitage, S. J., Lunn, H. R., Lu, H., 2007. Reinterpreting climate proxy records from late Quaternary Chinese loess: A detailed OSL investigation. Earth Science Reviews 80/1-2, Amsterdam. DOI: 10.1016/j.earscirev.2006.09.001

Stevens T., Lu, H., Thomas, D. S. G., Armitage, S. J., 2008. Optical dating of abrupt shifts in the Late Pleistocene East Asian monsoon. Geology 36-5, Boulder. DOI: 10.1130/G24524A.1

Stevens, T., Marković, S. B., Zech, M., Hambach, U., Sümegie, P. 2011: Dust deposition and climate in the Carpathian basin over an independently dated last glacial-interglacial cycle. Quaternary Science Reviews. Amsterdam. DOI: 10.1016/j.quascirev.2010.12.011

Újvári, G., Kovács, J., Varga, G., Raucsik, B., Marković, S. B. 2010: Dust flux estimates for the Last Glacial Period in East Central Europe based on terrestrial records of loess deposits. Quaternary Science Reviews 29/23-24. Amsterdam. DOI: 10.1016/j.quascirev.2010.07.005

Vandenberghe, J., Huijzer, B., Mücher, H., Laan, W. 1998: Short climatic oscillations in a western European loess sequence (Kesselt, Belgium). Journal of Quaternary Science 13/5. Chichester. DOI: 10.1002/ (SICI) 1099-1417(1998090)13:5

Vasiljević, Dj., Marković, S. B., Hose, T. A., Basarin, B., Lazić, L., Stojanović, V., Lukić, T., Vidić, N., Jović, G., Janićević, S., Samardžija, D. 2009: The Use of Web-Based Dynamic Maps in the Promotion of the Titel Loess Plateau (Vojvodina, Serbia), a Potential Geotourism Destination. Geographica Pannonica 13/ 3. Novi Sad.

Vasiljević, Dj. A., Marković, S. B., Hose, T. A., Smalley, I., Basarin, B., Lazić, L., Jović, G. 2011: The Introduction to Geoconservation of loess-palaeosol sequences in the Vojvodina region: Significant geoheritage of Serbia. Quaternary International. Amsterdam. DOI: 10.1016/j.quaint.2010.07.008

Vujičić, M. D., Vasiljević, Dj. A., Marković, S. B., Hose, T. A., Lukić, T., Hadžić, O. this issue: Preliminary Geosite Assessment Model (GAM) and Its Application on Fruška Gora Mountain, Potential Geotourism Destination of Serbia. Acta Geographica Slovenica, this issue. Ljubljana.

Wimbledon, W. A. P. 1996: National site selection, a stop on the way to a European Geosite list. Geologica Balcanica 26. Sofia.

Zech M., Buggle B., Leiber K., Marković S., Glaser B., Hambach U., Huwe B., Stevens T., Sümegi P., Wiesenberg G., Zöller L. 2009: Reconstructing Quaternary vegetation history in the Carpathian Basin, SE Europe, using n-alkane biomarkers as molecular fossils: problems and possible solutions, potential and limitations. Eiszeitalter und Gegenwart. Quaternary Science Journal 58/2. Chichester. DOI: 10.3285/eg.58.2.03

Zeeden, C., Hark, M., Hambach, U., Marković, S. B. Zöller, L. 2007: Depressions on the Titel loess Plateau: Form-Pattern-Genesis. Geographica Pannonica 11. Novi Sad. 